\title{
State Management and Corruption in Russia
}

\author{
V.V. Moiseev \\ Belgorod State Technological University named after V.G. Shukhov \\ Belgorod, 308012, Russia \\ din_prof@mail.ru
}

\begin{abstract}
The purpose of this study is to determine the causes and extent of corruption in public administration in modern Russia. Analyzing the activities of public authorities and management over the past two decades, you inevitably come to the conclusion that they are defeated by corruption. Corruption in the government under President V. Putin has increased several times. It has become the main source of enrichment for senior officials both in the federal center and in Russian regions. The main driving motive for their actions in the allocation of quotas, subsidies, tenders and tenders, public procurement and so on was personal gain. Therefore, the author defines corruption as the use of official position for personal gain. In conducting this study, the author posed the following basic questions. 1. The shortcomings of state management in the organization of counteraction to this crime.2. To identify what are the main reasons for the growth of corruption of government in 2000-2019.3. to compare methods of combating corruption in Russia and some other countries.
\end{abstract}

\section{Keywords—-fight against corruption; state management}

\section{INTRODUCTION}

Analyzing the results of state management during the reign of President V. Putin, the author came to the conclusion about its low efficiency [1]. The validity of this conclusion is evidenced by the results of socio-economic development over the past 20 years.

With huge natural resources (by some estimates, more than $30 \%$ of the world), developed human capital, and large financial resources from the sale of oil, gas, metal, coal, and other minerals, Russia can occupy a worthy place in the top five world powers. However, due to weak and ineffective governance, our country takes the 12th place in the world in economic development (according to the results of 2018). And according to the comfort of living, Russia belongs to the group of backward African countries. One of the reasons for this situation of a rich country is the massive corruption in power.

According to the corruption perception index calculated by the independent international organization Transparency International, in 2018, Russia ranked 138th out of 180 countries around the world, next to Nigeria, Iran and Kyrgyzstan [2].

A large number of books, brochures, scientific articles and dissertations are devoted to the problems of corruption and the reasons for its growth in Russia. So, G.I. Bondarenko, D.A., Lee, A.S. Makarychev, O.S. Novikova, A.V. Ponedelkov, A.M. Starostin, R.Kh. Usmanov investigated the causes of corruption in government [3].
The theoretical problems of determining the essence of corruption, the political science aspects of corruption relations and countering them at the state level are investigated in the works of Yu.M. Antonyana, G.I. Bogusha, I.A. Bondarenko, V.A. Vantseva, B.V. Volzhenkina, L. Gaukhman, A.I. Dolgovoy, I.Yu. Zhilina, A.M. Ivanova, P.A. Kabanova, V.V. Luneeva, Yu.G. Kozlova, M.V. Koroleva, A.G. Korchagin, N.F. Kuznetsova, I.I. Lukashuk, V.K. Maximova, G.K. Mishina, V.A. Nomokonova, I. Shikhaty and other scientists [4]. The criminal nature of corruption and legal methods of counteracting it are considered in the works of Russian criminologists and legal experts Vantseva V.A., Gaukhman L.D., Luneeva V.V., Maksimova S.V. and other authors. These and other Russian scientists come to the conclusion that the effectiveness of anti-corruption measures by state structures and civil society institutions is still extremely low, inadequate to the scale of this phenomenon and to threats to Russia's national security [5].

Unfortunately, in none of these works of domestic scientists, the role of President V. Putin in the growth of corruption in our country is shown. The author makes an attempt to fill this gap.

An analysis of the behavior of President V. Putin in the first two terms of his reign (2000-2008) shows that he not only did not take effective and decisive measures to combat corruption in government bodies but was even opposed to the adoption of anti-corruption legislation. In the period 20002008 President V. Putin twice vetoed anti-corruption laws passed by the Russian parliament. Moreover, by personally signing the UN Convention against Corruption in 2003, upon its ratification in 2006, he allowed excluding a number of important articles from this document, including criminal liability for the illegal enrichment and confiscation of property of corrupt officials [6].

In the absence of strict anti-corruption legislation, relevant ideological and organizational work against corruption, it is constantly growing and assuming an alarming scale. Owing to these and other reasons, the level of corruption in the Russian authorities only in the first presidential terms of V. Putin increased at least 5 times. The volume of corruption increased from $\$ 50$ billion in 2001 to $\$ 250$ billion in 2007. According to a study by the Indem Foundation, led by former Presidential Aide Georgy Satarov, from 2001-2005. the volume of corruption in the sphere of relations between government and business has increased almost 10 times [7, pp.77-78]. 


\section{PurPose AND Questions OF RESEARCH}

The aim of the study is the problem of increasing corruption in Russia.

The research questions were:

1. The shortcomings of state management in the organization of counteraction to this crime.

2. To identify what are the main reasons for the growth of corruption of government in 2000-2019.

3. To compare methods of combating corruption in Russia and some other countries.

By analyzing the current state of the fight against corruption, the author comes to a disappointing conclusion, namely: in the last two terms of V. Putin's work, the work of state management in the field of combating corruption has not led to positive results. Moreover, the greed of officials themselves in the Putin administration has increased dramatically. This is evidenced by numerous facts. For example, Minister of Economic Development A. Ulyukaev was imprisoned for a bribe of $\$ 2$ million. Over the past five years, many regional leaders appointed by President Vladimir Putin have been arrested and prosecuted for corruption. Among them: V. Dudka (Tula Region), A. Khoroshavin (Sakhalin Region), N. Denin (Bryansk Region), V. Gaizer (Komi Republic), N. Belykh (Kirov Region), P. Konkov (Ivanovo Region), V. Ishayev (Khabarovsk Territory) and others [8]. These leaders stole millions and billions of rubles from the state and society. Governor of Komi Vyacheslav Gaiser, arrested for corruption and fraud, he created a criminal group of 15 people, which included representatives of local authorities. The amount of damage from their illegal activities is 1 billion rubles [9]. The appointment of these officials to high posts, which they used for illegal enrichment, testifies to serious mistakes in the personnel policy of President V. Putin.

Yuri Chaika, Prosecutor General, made an unpleasant conclusion for the Russian authorities. He stated that corruption in Russia has acquired "systemic character" [10].

According to the Audit Chamber of the Russian Federation, more than \$ 15 billion was stolen from the federal budget through corruption schemes every year. The head of the Accounts Chamber, Sergey Stepashin, personally reported to President V. Putin about this glaring fact. However, the head of state did not take appropriate measures.

The Investigative Committee of Russia, the leadership of the prosecutor's office and the police claimed latency of this type of crime and difficulties in counteracting.

Due to the weakening of the work of government agencies designed to combat corruption appetites and greed of officials increased. So, police Colonel Dmitry Zakharchenko should fight corruption, as it was one of the leaders of the anticorruption structure in the Ministry of Internal Affairs of Russia. Instead, he actively enriched himself, using his official position. During the search, he was found a large amount of money - more than 8.5 billion rubles. In April 2019, three officers from the Federal Security Service (formerly the KGB), Kirill Cherkalin, Andrey Vasilyev and Dmitry Frolov, were arrested for corruption. These heirs of F. Dzerzhinsky robbed the state for 14 billion rubles [11].

Determining the reasons for the growth of corruption in Russian authorities, the author names the main ones:

a) Greed and impunity of corrupt officials,

b) Unsystematic and ineffective fight against corruption,

c) Lack of political will of the president of V. Putin,

d) Legislation, which contains a huge number of loopholes,

e) The absence of the institution of confiscation of property from corrupt officials

f) Underdevelopment of civil society and etc.

Due to the fact that decisive measures to combat corruption in Russia is not taken, it affects new and new state structures, and officials continue to rob the federal and regional budgets, businessmen and ordinary citizens. The bill went not billions, but trillions of rubles.

President of Russia V. Putin, in his many trips around the world, could, if he wanted, take an interest in the positive experience of many countries where they successfully counteract corruption in power. For example, actions aimed at reducing corruption have led to significant results in Finland, Denmark, Germany, Singapore, New Zealand, Georgia and other countries. These countries have proven in practice that there are effective forms and methods to combat corruption. It is vital for Russia to study them and use creatively in counteraction.

However, judging by the Kremlin's official reports on V. Putin's trips to these states, the Russian president was not interested in this topic. For example, having visited Singapore, which, thanks to a decisive fight against corruption of officials in a short historical period, turned from a backward colony into a prosperous state, the Russian president did not ask how they achieved it. Meanwhile, the analysis shows that Singapore has successfully used anti-corruption measures: strict laws, high salaries for ministers and judges ( 1 million US dollars per month), the inevitability of punishment for corrupt officials, personal examples of the correct behavior of senior executives, effective functioning of anti-corruption Department, etc. [12].

One of the most common forms of corruption in public administration is a conflict of interest. "Conflict of interest" provides for a situation in which an official's personal interest interferes with the objective performance of duties and he makes a decision and acts not in the interests of the state and society, but in his own selfish interests. At the same time, the official deliberately commits one or another action harmful to the state. Here are some examples of conflicts of interest for Russian officials. Moscow Mayor Yu. Luzhkov contributed to the enrichment of his wife, using his official position. According to Forbes, the President of the Inteko holding, Elena Baturina, the wife of Moscow mayor Yuri Luzhkov, ranked 34th in the ranking with $\$ 900$ million. According to other sources, the total income of the wife of the mayor of Moscow amounted to more than 7 billion rubles. 
St. Petersburg Governor V. Matvienko also took advantage of her official position to enrich her son, allocating him land for construction, bypassing tenders and competitions. Businessman Sergey Matvienko, with the support of his mother Valentina Matvienko, became the happy owner of 10 land plots and 9 buildings that previously belonged to the city, for a total of about 8.4 billion rubles, paying for them much less than their real value [13].

The complexity of studying the problem of corruption, the more so to prove a conflict of interest in a particular situation, lies in the fact that it is hidden. Therefore, it is often required to conduct a lengthy investigation, to collect evidence base in order to expose a corrupt official. It should be noted that corruption schemes in Russia are constantly being improved, they involve not only businessmen and individuals, but also enterprises and organizations registered in offshore. For example, Natalya Sergunina, the first deputy mayor of Moscow, who previously headed the capital's property department, profitably sold buildings that previously belonged to the city to her younger sister Irina and her husband through offshore companies. It took a lengthy special investigation by the Anti-Corruption Foundation (a public organization) to unravel criminal corruption schemes that caused significant material damage to Moscow [14].

\section{RESEARCH METHODS}

In this study, the following methods are used: comparative, institutional, systemic and structural-functional.

\section{CONCLUSION}

As a conclusion, the following should be noted.

1. Corruption has a negative impact on political and socioeconomic processes in Russian society. Its growth discredits the work of state and municipal authorities, strengthens citizens' distrust of the authorities, the reforms carried out in the country.

2. We are talking about the decomposition of the institutions of power, so the fight against corruption is a vital issue for Russia, without which it is impossible to achieve progress in the development of the country.

3. Russia needs to carefully study and creatively use the international anti-corruption Strategy.

4. Thus, such factors as the presence of powers related to the distribution of significant financial resources and material resources, a high degree of freedom of action in making managerial decisions within the framework of the assigned powers, and high intensity of contacts with citizens and organizations influence the level of corruption in government bodies.

\section{REFERENCES}

[1] Moiseev V.V. Why Russia can not yet become a prosperous country,” Moscow, Berlin, 2017, 681 p.; Moiseev V.V. State policy of economic development of modern Russia (2000-2016): monograph. M., Berlin, 2017, 346 p.; V.F. Nitsevich, V.V. Moiseev, O. A. Sudorgin, "To the Question of effectiveness of government Management”, European
Proceedings of Social and Behavioural Sciences, 2017, vol. XXXIV, pp 933-944.

[2] Russia in the Corruption Perception Index - 2018: 28 points out of 100 and 138th place. - URL: https://transparency.org.ru/research/indeksvospriyatiya-korruptsii/rossiya-v-indekse-vospriyatiya-korruptsii-201828-ballov-iz-100-i-138-mesto.html.

[3] Bondarenko G.I. Corruption as a form of interaction between human capital, business and government in a crisis // Actual problems of sociohumanitarian knowledge. M., 2006. Issue. Xv. 4.4- Pp. 22-26; Bondarenko I.A. Corruption: economic analysis at the regional level. St. Petersburg. 2001; Lee D.A. On the methodology for determining the comparative level of corruption in the regions of Russia // Law and Politics, 2000, Vol. 5; Makarychev A.S. Crime and corruption in the context of regional security problems: the experience of the Volga Federal District// Corruption in public authorities: nature, countermeasures, international cooperation. N. Novgorod, 2001. Pp. 150-156; Novikova O.S. Features of the formation of a regional anticorruption policy (in the North Caucasus) // Actual problems of sociohumanitarian knowledge. - M., 2006; Rudoy V.V., Starostin A.M. Ponedelkov A.V. Corruption and anti-corruption aspects of the state civil service / The problem of corruption: ways of interdisciplinary research: materials of the V International Scientific Conference "Russia and the East" (Astrakhan, September 4-6, 2009), Astrakhan, 2009, pp 7-10 .

[4] Antonyan Yu.M. Typology of corruption and corruption behavior // Sociology of corruption. Materials of the scientific-practical conference. M., 2003; Vantsev V.A. The problem of the legal definition of the concept of corruption // Corruption in Russia. Information and analytical materials. Vol. 3. M., 2001; Zhelanova S.A., Chinchikov A.A Corruption: a historiographic analysis of the problem // Bulletin of the Saratov State Academy of Law. 1995. No. 4; Kabanov P.A. The concept and criminological characteristics of political corruption // Investigator. 1998. No. 8; Corruption: Political, Economic, Organizational and Legal Problems / Ed. V.V. Luneeva. M., 2001; Kozlov Yu.G. Corruption: criminological and socio-political aspects // Law. 1998. No. 1; Koroleva M.V. Problems of corruption in various government bodies // Corruption and the fight against it. M., 2000; Korchagin A.G., Ivanov A.M. Comparative study of corruption and official crimes. Vladivostok, 2001; Kuznetsova N.F. Corruption in the system of criminal crimes // Bulletin of Moscow University. Series 11. Law, 1993. No. 1; Lukashuk I.I. International legal forms of the fight against corruption // Corruption: political, economic, organizational and legal problems / Ed. V.V. Luneeva. M., 2001; Maximov V.K. The concept of corruption in international and Russian law // Law and Security. 2002. No. 2-3 (3-4); Timofeev L.M. Institutional corruption: Essays on the theory of M., 2000; Timofeev L.M. Shadow Russia: Economic and sociological research. M., 2000, etc.

[5] Vantsev V.A. Corruption crime. M., 2002; Gaukhman L. Corruption and corruption crime // Legality. 2000. No. 6; State and law. 2000, No. 4; Luneev V.V. The experience of combating organized and corruption crime in Italy // Organized crime, terrorism and corruption: Criminological quarterly almanac. Vol. 1, 2003; Maximov S.V. Corruption. Law. A responsibility. M., 2000; Kabanov P.A. The concept and criminological characteristics of political corruption // Investigator. 1998. No. 8 et al .

[6] V.V. Moiseev, V. F. Nitsevich, O. A. Sudorgin. Corruption in Russia a threat to national security/ The European Proceedings of Social \& Behavioural Sciences, 2018, Vol. XXXV, pp. 831-843.

[7] Moiseev V.V., Prokuratov V.N. Anti-corruption in modern Russia. Eagle: APLIT, 2012, 514 p

[8] Moiseev V. V., Karelina, E. A., Sudorgin, O. A. Corruption in Russia a Threat to national Security. European Proceedings of Social and Behavioural Sciences, 2018, Vol. 50, pp. 831-843.

[9] The court sent under arrest the head of the Republic of Komi. - URL: https://www.rbc.ru/politics/20/09/2015/55fe97d79a7947952654a1fb.

[10] Corruption pervades all levels of power. - URL: http://2006.novayagazeta.ru/nomer/ 2006/90 n/n90n-s20.shtml.

[11] 12 billion rubles seized from arrested colonel of FSB. - URL: https://www.gazeta.ru/social/2019/05/17/12362209.shtml

[12] Moiseev V.V. "Singapore miracle": how to become prosperous 
country. Man and Labor, 2011, Vol. 3, pp. 15-17.

[13] As the son of Valentina Matvienko, Petersburg got his hands on it. Part two. - URL: https://pasmi.ru/archive/200969/

[14] FBK: Deputy Mayor Sobyanin stole billions from Moscow. - URL: https://fbk.info/blog/post/514/ 